\title{
Pengaruh Pendekatan Conceptual Problem Solving terhadap Problem Solving dan Pemahaman Konsep Siswa SMA Negeri 3 Palu
}

\author{
Oka Saputra, I Komang Werdhiana, Darsikin \\ oucckha@gmail.com \\ Program Studi Magister Pendidikan Sains Pascasarjana Universitas Tadulako \\ Kampus Bumi Tadulako, Palu, Indonesia
}

\begin{abstract}
Abstrak - Penelitian ini bertujuan untuk mengetahui pengaruh pendekatan conceptual problem solving terhadap problem solving dan pemahaman konsep siswa SMA Negeri 3 Palu. Desain penelitian adalah eksperimen kuasi dengan Pretest-posstest Equivalent Group Design. Populasi penelitian adalah seluruh siswa kelas XI IPA SMA Negeri 3 palu. Teknik pengambilan sampel adalah purposive sampling. Kelas XI IPA 6 sebagai kelas eksperimen dan kelas XI IPA 7 sebagai kelas kontrol. Instrumen digunakan berupa uraian tes. Analisis data menggunakan Uji t dengan menggunakan aplikasi SPSS 20,0 pada taraf signifikansi 0,05 dengan uji prasyarat normalitas dan homogenitas. Hasil uji statistik problem solving diperoleh Sig. $=0,000$ dan pemahaman konsep Sig. = 0,000 dengan kriteria terima $\mathrm{H}_{\circ}$ jika Sig. $>0,05$ dan tolak $\mathrm{H}_{0}$ jika Sig. < 0,05. Nilai Sig. $<0,05$ sehingga $\mathrm{H}_{1}$ diterima dan $\mathrm{H}_{0}$ ditolak dengan kesimpulan terdapat pengaruh pendekatan conceptual problem solving terhadap problem solving dan pemahaman konsep siswa SMA Negeri 3 Palu.
\end{abstract}

Kata Kunci: conceptual problem solving, problem solving, pemahaman konsep

\section{PENDAHULUAN}

Pemecahan masalah (problem solving) merupakan bagian yang sangat penting dalam proses pembelajaran atau penyelesain soal-soal pemahaman konsep dalam fisika karena siswa akan mendapatkan pengalaman menggunakan pengetahuan serta keterampilan yang sudah dimiliki untuk diterapkan dalam soal-soal fisika [1].

Dewasa ini pembelajaran fisika yang dilakukan dengan pendekatan pemecahan masalah secara matematis cenderung mengakibatkan siswa hanya sekedar memahami matematika dalam fisika, kurang memahami pemahaman konsep-konsep fisika yang ada dan kurangnya kemampuan memecahkan masalah [2]. Hal tersebut diakibatkan karena pembelajaran menggunakan pendekatan pemecahan masalah yang seharusnya dapat memahami prinsip kerja tetapi hanya terfokus pada persamaan matematis untuk memecahkan masalah tersebut [3].

Beberapa peneliti sebelumnya [4][5][6] menyimpulkan bahwa salah satu pendekatan pembelajaran fisika yang dapat membuat siswa aktif dan dapat memahami prinsip dari apa yang telah diajarkan guru adalah pendekatan conceptual problem solving (CPS). CPS adalah sebuah pendekatan yang dilakukan oleh guru ketika mengajar, dimana ketika guru memberikan persoalan kepada siswa, siswa tersebut harus mengetahui bagimana prinsip dari permasalahan yang diberikan, justifikasi dari permasalahan dan bagaimana rencana mereka untuk memecahklan masalah tersebut. CPS mampu meningkatkan produktivitas problem solving siswa dibandingkan pendekatan tradisional yang banyak diterapkan oleh banyak guru [7].

Di Indonesia sendiri pendekatan CPS masih sangat asing didengar oleh kalangan pendidik terutama guru. Dengan mengacu pada artikel penelitian yang telah dipaparkan pada paragraf di atas sehingga peneliti ingin menerapkan pendekatan CPS pada kurikulum yang berlaku di Indonesia. Dalam rancangan rencana pembelajaran (RPP) yang dilakukan oleh guru juga memuat 3 langkah CPS dimana siswa mengetahui prinsip dari permasalahan yang diberikan, justifikasi dan bagaimana mereka memecahkan masalah tersebut.

Berdasarkan uraian di atas maka penelitian yang akan dilakukan penelitian dengan judul pengaruh pendekatan conceptual problem solving terhadap problem solving dan pemahaman konsep siswa SMA Negeri 3 Palu.

\section{METODOLOGI PENELITIAN}

Jenis penelitian ini merupakan penelitian kuantitatif yang bersifat eksperimen kuasi. Desain yang digunakan dalam penelitian ini adalah "two group pretest-posttest design" yaitu penelitian yang dilaksanakan dengan 
menggunakan dua kelas, kelas pertama merupakan kelas kontrol dan kelas berikutnya merupakan kelas eksperimen [8]. Desain penelitian ini dapat dilihat pada Tabel 1:

TABEL 1. DESAIN DUA KELOMPOK PRETEST-POSTTEST (TWO GROUP PRETEST POSTTEST DESIGN)

\begin{tabular}{cccc}
\hline Kelompok & Tes Awal & Perlakuan & $\begin{array}{c}\text { Tes } \\
\text { Akhir }\end{array}$ \\
\hline $\mathrm{E}$ & $\mathrm{O}_{1}$ & $\mathrm{X}$ & $\mathrm{O}_{2}$ \\
$\mathrm{~K}$ & $\mathrm{O}_{1}$ & & $\mathrm{O}_{2}$ \\
\hline
\end{tabular}

Keterangan:

E : Kelas eksperimen

$\mathrm{K}$ : Kelas kontrol

$X$ : Perlakuan dengan pendekatan CPS.

$\mathrm{O}_{1}$ : Tes Awal

$\mathrm{O}_{2}$ : Tes Akhir

Adapun populasi dalam penelitian adalah seluruh siswa kelas XI SMA Negeri 3 Palu tahun pelajaran 2016/2017 yang terdiri dari 8 kelas. Kelas XI IPA 7 dijadikan sebagai kelas kontrol dan kelas XI IPA 6 digunakan menjadi kelas eksperimen yang dipilih dengan menggunakan teknik purposive sampling.

Data yang diperoleh dalam bentuk hasil tes problem solving dan pemahaman konsep. Data yang dikumpulkan dari penelitian ini selanjutnya diolah dengan menggunakan teknik analisis deskriptif yaitu pengskoran nilai jawaban siswa, rata-rata nilai dan standar deviasi. Untuk menghitung nilai rata-rata siswa dan standar deviasi digunakan rumus sebagai berikut [9]:

$$
\begin{aligned}
& >\bar{X}=\frac{\sum X i}{n} \\
& >S D=\sqrt{\frac{\sum\left(X_{i}-\bar{X}\right)^{2}}{n}}
\end{aligned}
$$

Keterangan:

$\bar{x} \quad$ : rata-rata nilai yang diperoleh siswa

$\mathrm{n}$ :banyaknya sampel

SD : standar deviasi

Kategori tinggi, diperoleh dengan rumus:

Nilai $>\bar{X}+(0,5 . S D)$

Kategori sedang, diperoleh dengan rumus:

$\bar{X}-(0,5 . S D) \leq$ Nilai $\leq \bar{X}+(0,5 . S D)$

Kategori rendah, diperoleh dengan rumus:

$$
\text { Nilai }<\bar{X}-(0,5 . S D)
$$

Tahap berikutnya pengujian statistik untuk menentukan hasil yang ditarik dalam penelitian ini menggunakan $u j i ~ t, ~ t a t a p i ~ s e b e l u m$ menggunakan $u j i \mathrm{t}$ data tersebut harus di $u j i$ dulu dengan uji normalitas dan uji homogenitas. Semua data dalam penelitian ini menggunakan SPSS 20.2 .

\section{HASIL DAN PEMBAHASAN}

Dalam penelitian instrumen yang digunakan berupa tes problem solving yang terdiri dari 4 soal dalam bentuk uraian dan tes pemahaman konsep yang terdiri dari 5 soal uraian. Setiap item soal tes telah divalidasi oleh validator ahli.

Setelah dilakukan perhitungan tes problem solving dan pemahaman konsep diperoleh data hasil penelitian seperti pada Tabel 2 dan 3 .

TABEL 2. SKOR TES PROBLEM SOLVING KELAS EKSPERIMEN DAN KELAS KONTROL

\begin{tabular}{ccccccc}
\hline \multicolumn{2}{c}{ Kelas eksperimen } & & \multicolumn{2}{c}{ Kelas kontrol } & \multirow{2}{*}{ Tes } \\
\cline { 2 - 3 } Uraian & Tes & Tes & & Uraian & Tes & Akhir \\
\cline { 2 - 5 } & Awal & Akhir & & Sampel & 38 & 38 \\
Sampel & 38 & 38 & & Skor Terendah & 9 & 13 \\
Skor Terendah & 9 & 24 & & Skor Tertinggi & 17 & 22 \\
Skor Tertinggi & 15 & 32 & & Skor Rata-rata & 12,28 & 17,57 \\
Skor Rata-rata & 12,05 & 28,44 & & Skor Ideal & 32 & 32 \\
Skor Ideal & 32 & 32 & & Standar Deviasi & 2,24 & 1,78 \\
Standar Deviasi & 1,75 & 1,85 & . & &
\end{tabular}

TABEL 3.SKOR TES PEMAHAMAN KONSEP KELAS EKSPERIMEN DAN KELAS KONTROL

\begin{tabular}{cccccc}
\hline & \multicolumn{3}{c}{ Kelas eksperimen } & & Kelas kontrol \\
\hline \multirow{2}{*}{ Uraian } & Tes & Tes & Uraian & Tes & Tes \\
\cline { 2 - 6 } & Awal & Akhir & & Awal & Akhir \\
\hline Sampel & 38 & 38 & Sampel & 38 & 38 \\
Skor Terendah & 2,25 & 7,5 & Skor Terendah & 2,25 & 5,5 \\
Skor Tertinggi & 6,25 & 10,5 & Skor Tertinggi & 6,25 & 9,5 \\
Skor Rata-rata & 4,59 & 9,97 & Skor Rata-rata & 4,27 & 6,86 \\
Skor Ideal & 10,5 & 10,5 & Skor Ideal & 10,5 & 10,5 \\
Standar Deviasi & 0,95 & 0,72 & Standar Deviasi & 1,15 & 1,07 \\
\hline
\end{tabular}

Untuk menguji normalitas suatu data termasuk data hasil penelitian ini digunakan persamaan chi kuadrat. Data yang digunakan untuk uji normalitas meliputi 1) tes awal kelas eksperimen, 2) tes awal kelas kontrol. Diperoleh hasil pengujian normalitas seperti

\begin{tabular}{|c|c|c|}
\hline Uraian & Pemahaman konsep & Problem solving \\
\hline Sampel & 38 & 38 \\
\hline X2hitung kelas eksperimen & 0,243 & 0,056 \\
\hline X2hitung kelas kontrol & 0,267 & 0,062 \\
\hline signifikansi & 0,05 & 0,05 \\
\hline Keterangan & Normal & Normal \\
\hline
\end{tabular}
disajikan Tabel 4 berikut.

TABEL 4. UJI NORMALITAS DATA TES

Berdasarkan pengujian normalitas baik pada kelas kontrol dan kelas eksperimen dengan taraf signifikan 0,05 diperoleh $\chi_{\text {hitung }}^{2}>0,05$ maka data terdistribusi normal.

Untuk uji homogenitas diperoleh hasil seperti ditunjukkan pada Tabel 5.

\begin{tabular}{ccc}
\multicolumn{2}{c}{ TABEL 5. UJ HOMOGENITAS DATA TES } \\
\hline Uraian & $\begin{array}{c}\text { Pemahaman } \\
\text { Konsep }\end{array}$ & $\begin{array}{c}\text { Problem } \\
\text { Solving }\end{array}$ \\
\hline Sampel & 38 & 38 \\
F hitung & 0,197 & 0,737 \\
signifikansi & 0,05 & 0,05 \\
Keterangan & Homogen & Homogen \\
\hline
\end{tabular}

Hasil pengujian homogenitas varians data dengan taraf signifikan 0,05 kelas kelas kontrol dan kelas eksperimen pada tabel 4. Dapat dilihat bahwa Fhitung berada pada daerah penerimaan $\mathrm{H}_{\mathrm{o}}$ dengan demikian data tersebut 
menunjukkan kedua kelas yang dijadikan sampel berasal dari populasi yang homogen.

Pengujian hipotesis menggunakan statistik parametrik (uji-t) dua variabel bebas (uji dua pihak) dilakukan setelah diperoleh bahwa hasil data pada tes awal dan tes akhir untuk tes problem solving dan pemahaman konsep antara kelas eksperimen pertama dan kelas kontrol berdistribusi normal dan homogen.

Hasil perolehan pengujian statistik data hasil tes problem solving dan pemahaman konsep antara kelas eksperimen pertama dan kelas kontrol ditunjukkan pada Tabel 6 .

TABEL 6. UJI HIPOTESIS

\begin{tabular}{ccc}
\hline Uraian & $\begin{array}{c}\text { Pemahaman } \\
\text { konsep }\end{array}$ & $\begin{array}{c}\text { Problem } \\
\text { solving }\end{array}$ \\
\hline Sig. & 0,000 & 0,000 \\
Ho & ditolak & ditolak \\
\hline
\end{tabular}

Untuk pengujian berdasarkan tes akhir dengan menggunakan rata-rata skor diperoleh Sig. 0,000 untuk pemahaman konsep dan problem solving dimana nilai Sig. $<0,05, \mathrm{H}_{\circ}$ ditolak dan hipotesis satu $\left(\mathrm{H}_{1}\right)$ diterima. Artinya ada pengaruh pendekatan CPS terhadap problem solving dan pemahaman konsep siswa SMA Negeri 3 Palu.

Analisis postest menggunakan SPSS 20.0 untuk $u j i ~ t$ terlihat bahwa hasil analisis kuantitatif kemampuan memecahkan masalah fisika menunjukkan skor rata-rata siswa kelas eksperimen 28,44 dan skor rata-rata kelas kontrol 17,57. Hasil ini menunjukkan bahwa terdapat perbedaan skor antara kelas eksperimen dan kelas kontrol terlihat bahwa skor kelas eksperimen lebih tinggi dibandingkan kelas kontrol. Hasil ini juga didukung oleh analisis uji statistik pada pengujian hipotesis dengan menggunakan rumus $\mathrm{Uji}-\mathrm{t}$ dengan taraf $a=0,05$. Dari perhitungan hipotesis diperoleh nilai Sig 0,00. Hasil pengujian hipotesis menunjukkan bahwa Sig. < 0,05 yaitu 0,000< 0,05 dengan kata lain hipotesis $\mathrm{H}_{1}$ diterima. Berdasarkan hasil pengujian hipotesis dapat disimpulkan bahwa ada pengaruh pendekatan conceptual problem solving secara signifikan terhadap kemampuan siswa dalam memecahkan masalah fisika pada materi elastisitas siswa kelas XI SMA Negeri 3 Palu.

Pada skor akhir (postest) pada kelas eksperimen dan kelas kontrol cukup berbeda. Rata-rata skor untuk kelas eksperimen sebesar 28,44 sedangkan kelas kontrol sebesar 17,57. Secara kuantitas hasil ini menunjukkan perbedaan yang signifikan harga tersebut menunjukkan kelas eksperimen memperoleh skor rata-rata yang tinggi dibandingkan dengan kelas kontrol.
Materi yang diajarkan pada kelas kontrol dan kelas eksperimen yaitu materi elastisitas. Elastisitas dalam fisika sangat erat dengan kehidupan sehari-hari yang dialami oleh siswa dan mereka tanpa sadar bahwa sesuatu yang mereka kerjakan dalam keseharian mereka tidak luput dari elastisitas misalkan saja saat berpergian menggunakan kendaraan yang menggunakan pegas. Pendekatan CPS merupakan pendekatan pembelajaran yang didalamnya menggajarkan siswa untuk lebih aktif dalam berpikir dan memecahkan masalah dalam kehidupan sehari-hari. Oleh karena itu peneliti dalam studi ini mencoba memilih materi bahan ajar elastisitas dengan pendekatan CPS.

Dari hasil analisis data yang telah dilakukan, peneliti membagi 3 jenis kategori untuk masing-masing kelas baik kelas eksperimen dan kelas kontrol. Kategori tersebut adalah jawaban dengan nilai tinggi, jawaban dengan nilai sedang dan jawaban dengan nilai rendah.

Jawaban dengan nilai tinggi pada kelas eksperimen dan kelas kontrol memiliki variasi jawaban yang berbeda, ada yang kedua jawaban dari masing-masing kelas benar dan ada juga yang salah satunya benar. Soal yang dijawab benar baik kelas eksperimen dan kelas kontrol pada kategori tinggi adalah soal nomor 1 dengan jawaban sebagai bebrikut:

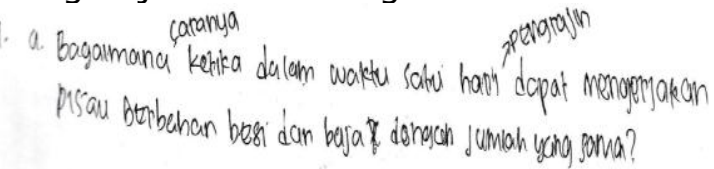

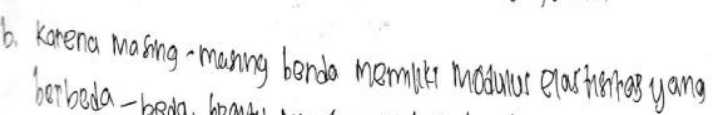

$$
\begin{aligned}
& \text { berboda - beda. begrta juga dongan begr dan baja. modu'us elasti- } \\
& \text { that? bess leberh keal sariperda baja. Sehingga, lebin mudah wherjo. } \\
& \text { c. Jadi caranyou titu dergan menggumakan alat yang belar Sehingog }
\end{aligned}
$$

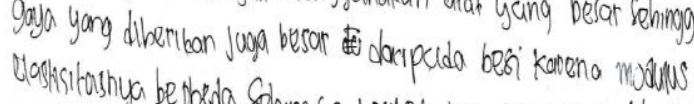

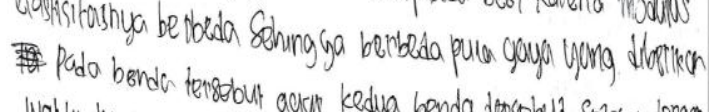

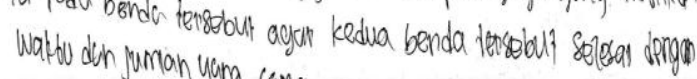

$$
\begin{aligned}
& \text { Gbr 1. Jawaban problem solving kategori tinggi kelas }
\end{aligned}
$$




$$
\begin{aligned}
& \begin{array}{l}
\text { 1. A. Bagaimana caranya pisau berbahan besi dan pisan } \\
\text { berbahan bagh dapat selesai dalam satu havi dingan } \\
\text { Jumlah yang sama? }
\end{array} \\
& \text { b. Karna baja menviliki modulus elastisitus yang } \\
& \text { pesar, sehingga butuh waktu yang lama untuk siproses. } \\
& \text { sedangean bes memiliki bur modulus elastifitus yang } \\
& \text { kecil, sehingga mudah untuk ditelola } \\
& \text { C. }
\end{aligned}
$$

Gbr. 2. Jawaban problem solving kategori tinggi kelas kontrol

Dari jawaban tersebut kelas yang diajar dengan pendekatan pendekatan CPS mampu mengisi jawaban dengan 3 tahapan problem solving dengan benar. 3 tahapan problem solving yang diukur dalam penelitian ini adalah pemahaman terhadap masalah, membuat perencanaan masalah dengan konsep dan menyelesaikan masalah tersebut. Sementara kelas yang di ajarkan dengan kelas kontrol hanya mampu menjawab 2 tahapan problem solving yang akan di ukur yaitu pemahaman masalah dan membuat rencana, tetapi belum dapat menyelesaikan soal tersebut secara sepenuhnya. Hal tersebut tersebut dimungkinkan karena dalam pembelajaran menggunakan pendekatan CPS, siswa berperan aktif dalam proses pembelajaran dan secara kreatif berusaha menemukan solusi dari permasalahan yang diajukan, saling berinteraksi dengan teman maupun guru, saling bertukar pikiran, sehingga wawasan dan daya pikir mereka berkembang dan menyadari banyak hal atau kejadian yang dapat mereka jumpai dalam kehidupan seharihari yang berkaitan dengan konsep fisika yang mereka pelajari. Salah satu contoh pada materi elastisitas dimana peneliti menanyakan: "jika kalian cermati, mengapa pegas yang ditarik dengan gaya yang lebih besar panjangnya juga bertambah?". Secara antusias siswa menjawab pertanyaan yang diberikan sesuai yang mereka lihat dalam kehidupan sehari-hari. Disini terjadi perdebatan antara siswa sehingga menjadikan mereka penasaran dengan jawaban yang sebenarnya. Peneliti belum memberikan jawaban melainkan melanjutkan dengan memberikan materi tentang elastisitas guna menanamkan konsep yang diperlukan untuk menyelesaikan masalah yang dihadapi. Setelah siswa telah memahami dengan materi elastisitas kemudian peneliti menanyakan kembali tentang pertanyaan awal yang menghadirkan kontra dan secara langsung siswa menjawab pertanyaan tersebut sesuai dengan konsep yang diajarkan. Pada tahap ini siswa bisa menyadari akan banyak hal dan menyadari akan makna dari belajar fisika [10].

Tahap selanjutnya yaitu tahap inti dari model CPS dimana siswa dituntut untuk berdiskusi kelompok guna bertukar pikiran dalam menghasilkan beragam ide-ide permasalahan yang mereka jumpai dalam kehidupan seharihari dan bagaimana menyelesaikan permasalahan tersebut berdasarkan konsep yang telah mereka pelajari. Salah satu ide masalah yang mereka peroleh pada penerapan elastisitas dalam kehidupan sehari-hari yaitu "mengapa katapel yang digunakan Alif putus jika diberikan gaya terus menerus?". Siswa mencoba menjawab pertanyaan tersebut secara berkelompok dan mencoba menggunakan literatur yang ada guna mendukung dalam menyelesaikan permasalahan yang dihadapi. Pada tahap ini siswa mampu mengembangkan ide, wawasan dan kreatifitas mereka yang menjadikan mereka menjadi aktif dalam proses pembelajaran dan yang utamanya adalah mereka mendapatkan makna dari belajar ilmu fisika yang ternyata dapat bermanfaat dalam kehidupan sehari-hari. Hasil ini sejalan dengan kelebihan dengan problem solving yang ada pada literatur dimana siswa diantaranya mampu menyelesaikan masalah secara realistis dan berpikir serta bertindak secara kreatif. Selain itu, ini juga sejalan dengan apa yang dirasakan oleh siswa dimana mereka merasakan asyiknya belajar fisika [9]. Salah satu siswa mengatakan bahwa "dengan belajar seperti ini kami menyadari akan banyak hal dari permasalahan-permasalahan yang dijumpai dalam kehidupan sehari-hari yang ternyata berkaitan dengan konsep fisika yang mereka pelajari". Hal ini menunjukkan bahwa dengan belajar dengan menggunakan model CPS siswa dapat merasakan makna dari belajar fisika.

Untuk kategori sedang pada kelas eksperimen dan kelas kontrol juga memiliki variasi jawaban yang sama dengan kategori tinggi, misalkan soal nomor 1 baik kelas eksperimen dan kelas kontrol menjawab dengan jawaban yang berbeda seperti yang terlihat pada gambar di bawah ini: 
a. Bagamana cara ayahteu cogar dapat mencederialkar pisau tersebut secara bersamoan?

b. Konsep apa yang hans dogunakan ayah untuk mempertimbangkon peambovaton pisav tersebut?

C. Baja merupakan benda yg sangat keras dan susah dibenve Sehinga, pengerjaan pambuatem pisau dar baja, hans mungaunakan martil/palu-palu yg lebuh besar clari pada baja ty mau dibentuk.

Gbr. 3. Jawaban problem solving kategori sedang kelas eksperimen

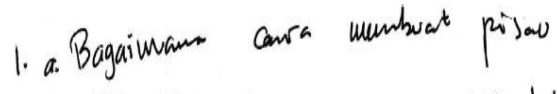

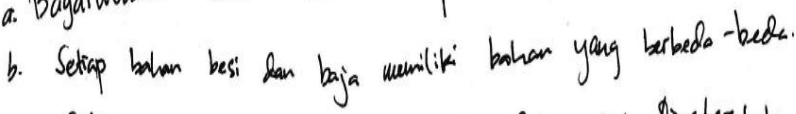

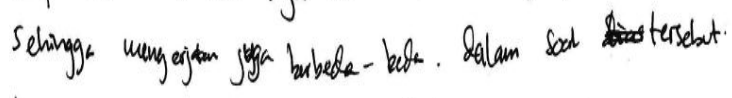

$$
\begin{aligned}
& \text { bes: terin keras sibandingan baja. }
\end{aligned}
$$$$
\text { c. Dedur unngujakar baja aych harus lebile rajih. }
$$

Gbr. 4. Jawaban problem solving kategori sedang kelas kontrol

Perbedaan yang mencolok dari paparan jawaban siswa di atas terjadi pada soal bagian merencanakan masalah dengan konsep sampai menyelesaikan masalah. Kedua anak baik kelas kontrol dan kelas eksperimen mampu memahami masalah dengan baik. Pada bagian memahami konsep anak pada kelas eksperimen hanya menjawab soal secara umum tetapi tidak spesifik kemudian pada bagian menyelesaikan masalah anak pada kelas eksperimen menjawab dengan benar sementara anak yang diajarkan dengan pembelajaran konvensional terbalik dalam menyelesaikan permasalahan yang diberikan.

Dari kategori jawaban diatas bisa ditarik kesimpulan bahwa kelas eksperimen menjawab dengan baik ketiga tahapan problem solving dibandingkan kelas kontrol karena pembelajaran konvensional yang diajarkan pada kelas kontrol hanya menekankan pada ingatan siswa saja. Sementara pendekatan CPS adalah salah satu pendekatan pembelajaran yang dapat digunakan untuk meningkatkan kemampuan siswa dalam memecahkan masalah fisika.

Pendekatan CPS memiliki enam tahapan pembelajaran yang dapat meningkatkan kemampuan siswa dalam memecahkan masalah fisika. Tahap pertama yaitu mengorientasi siswa pada masalah, tahap ini bertujuan untuk menggali pengetahuan awal siswa yang berkaitan dengan masalah-masalah konseptual. Tahap kedua yaitu mendeskripsikan masalah, dalam bentuk fisika tahap ini tahap ini guru mengorganisaikan siswa dalam kelompok kecil (4-6 siswa dalam tiap kelompok) yang diperlukan untuk memudahkan siswa dalam menemukan dan memecahkan masalah fisika secara bersama (brain storming) serta penanaman konsep yang diperlukan siswa dalam memecahkan masalah fisika dan di maksudkan mampu memahami masalah dalam bentuk fisika. Tahap ketiga yaitu merencanakan solusi, tahap ini siswa sudah memahami masalah dalam bentuk fisika dan telah melakukan percobaan dan diharuskan menjawab soal sesuai dengan percobaan yang dilakukan atau yang berkaitan dengan percobaan. Tahap empat yaitu melaksanakan rencana tersebut, pada tahap ini siswa sudah mendapatkan solusi untuk setiap soal yang diberikan dan siswa hanya perlu menuliskan jawaban dari soal yang telah diberikan guru. Tahap kelima yaitu mengevaluasi, tahap ini guru memberikan jawaban yang benar pada soal yang diberikan dan mempersilahkan siswa untuk bertanya jika ada yang belum jelas dari materi yang telah dipelajari.

Pendekatan CPS merupakan pendekatan pembelajaran yang berpusat pada masalah. Selain itu pendekatan CPS juga dapat meningkatkan aktifitas dan berpikir kreatif siswa dalam proses pembelajarannya. Penelitian pendekatan CPS di SMA Negeri 3 Palu memiliki pengaruh signifikan dibandingkan dengan model pembelajaran konvensional. Terlepas dari semua itu, peneliti juga memperoleh beberapa hambatan berdasarkan pengamatan dalam proses pembelajaran CPS diantaranya: (a) Tujuan dari dibentuknya kelompok-kelopok kecil belum telaksana secara keseluruhan dimana siswa cenderung mendiskusikan hal-hal diluar materi pelajaran bila siswa tidak diawasi. (b) Siswa masih menemukan hambatan dalam menemukan ideide permasalahan maupun dalam memecahkan masalah yang dihadapi hal ini disebabkan karena sumber belajar yang masih kurang sehingga siswa cukup kesulitan dalam menemukan informasi-informasi yang dibutuhkan dalam memecahkan masalah. (c) membutuhkan alokasi waktu yang cukup lama.

Untuk kategori rendah pada kelas eksperimen dan kelas kontrol juga memiliki variasi jawaban yang sama dengan kategori tinggi dan sedang, misalkan soal nomor 6, kelas eksperimen menjawab dengan benar dan kelas kontrol menjawab dengan jawaban yang benar tetapi 
alasan kurang tepat seperti yang terlihat pada gambar dibawah ini:

$$
\begin{aligned}
& \text { 4. Dk: } k_{1}=k_{2}=k_{3}=k \\
& \Delta x_{3}=4 \mathrm{~cm} \\
& \text { Dif : } \Delta x+\text { ? } \\
& \text { pen: } \\
& K_{t}=\left(k_{1} \text { Paralel } K_{2}\right) \text { ser- } k_{3} \\
& =\left(k_{1}+k_{2}\right) \text { serl } k_{3} \\
& =(k+k) \text { serl } k_{3} \\
& =2 k \text { seti } k \\
& =\frac{(2 k)(k)}{2 k+k} \\
& =\frac{2 k^{2}}{3 k} \\
& =\frac{2}{3} k \ldots . \text { pors (1) } \\
& F_{3}=k_{3} \Delta x_{3} \\
& M g=K(4 \mathrm{~cm}) \rightarrow K=\frac{M g}{4 \mathrm{~cm}} \cdots \ldots . . \text { pors (2) } \\
& \text { Jadi; } \\
& F=K_{t} \Delta x_{t} \\
& M_{g}=\left(\frac{2}{3} k\right) \Delta x_{f} \quad \text { (subtilusi } F=M g \text { dan } k_{t}=\frac{2}{3} k \\
& M g=\left(\frac{2}{3}\right)\left(\frac{m g}{4 c m}\right) \Delta x+ \\
& \Delta x+=
\end{aligned}
$$

Gbr. 5. Jawaban problem solving kategori rendah kelas eksperimen

$$
\text { 4. } \begin{aligned}
\text { Dik } & =k_{1}=k_{2}=k_{3}=k_{;} \Delta x_{3}=4 \mathrm{~cm} ; \\
\text { Dit } & =\Delta x_{1} \ldots .7 \\
k_{t} & =\left(k_{1} \text { paralel } k_{3}\right) \text { seri } k_{2} \\
& =\left(k_{1}+k_{3}\right) \text { seri } k_{2} \\
& =(k+k) \text { seri } k_{2}
\end{aligned}
$$

Gbr. 6. Jawaban problem solving kategori rendah kelas kontrol

Jawaban diatas bisa dilihat perbedaan jawaban siswa, walaupun kedua siswa dari kelas kontrol dan eksperimen belum mencapai skor maksimal dalam memecahkan masalah dalam soal hitungan tetapi terdapat perbedaan dalam kategori rendah pada jawaban siswa tersebut. Siswa yang diajarkan dengan pendekatan CPS sudah mampu mendeskripsikan jawaban dengan benar, perencanaannnya benar walaupun jawaban akhir masih belum seperti yang diharapkan. Sementara pada kelas kontrol siswa hanya mampu mendeskripsikan soal dengan benar tetapi pada tahapan perencanaan masih salah dan akhirnya tidak akan menjawab pada tahapan berikutnya yaitu pada bagian jawaban akhir. Hal tersebut dikarenakan kelas kontrol yang diterapkan pembelajaran konvensional sebagai pembandingnya, siswa dalam kegiatan pembelajaran lebih banyak berpikir sendiri dan kurang aktif dalam kegiatan pembelajaran. Hal ini dapat berpengaruh terhadap kemampuan memecahkan masalah fisika siswa karena siswa tidak secara aktif dan kreatif dalam proses pembelajaran yang seharusnya siswa lebih banyak berperan. Ada juga kemungkinan siswa seperi pada kelas eksperimen diatas tidak menjawab dengan benar soal yang diberikan dimungkinkan karena siswa kurang perhatian ketika guru menjelaskan materi yang berkaitan.

Analisis postest pemahaman konsep terlihat bahwa hasil analisis kuantitatif pemahaman konsep fisika menunjukkan skor rata-rata siswa kelas eksperimen 9,97 dan skor rata-rata kelas kontrol 6,86. Hasil ini menunjukkan bahwa terdapat perbedaan skor antara kelas eksperimen dan kelas kontrol terlihat bahwa skor kelas eksperimen lebih tinggi dibandingkan kelas kontrol. Hasil ini juga didukung oleh analisis uji statistik pada pengujian hipotesis dengan menggunakan rumus $\mathrm{Uji}-\mathrm{t}$ dengan taraf $a=0,05$. Dari perhitungan hipotesis diperoleh nilai Sig 0,00. Hasil pengujian hipotesis menunjukkan bahwa Sig. $<0,05$ yaitu 0,000 < 0,05 dengan kata lain hipotesis $\mathrm{H}_{1}$ diterima. Berdasarkan hasil pengujian hipotesis dapat disimpulkan bahwa ada pengaruh pendekatan conceptual problem solving secara signifikan terhadap pemahaman konsep pada materi elastisitas siswa kelas XI SMA Negeri 3 Palu.

Dari hasil analisis data yang telah dilakukan, peneliti membagi 3 jenis kategori untuk masing-masing kelas baik kelas eksperimen dan kelas kontrol. Kategori tersebut adalah jawaban dengan nilai tinggi, jawaban dengan nilai sedang dan jawaban dengan nilai rendah.

Jawaban dengan nilai tinggi pada kelas eksperimen dan kelas kontrol memiliki variasi jawaban yang berbeda, ada yang kedua jawaban dari masing-masing kelas benar dan ada juga yang salah satunya benar. Soal yang dijawab benar baik kelas eksperimen dan kelas kontrol pada kategori tinggi adalah soal nomor 5 dengan jawaban sebagai berikut:

5.

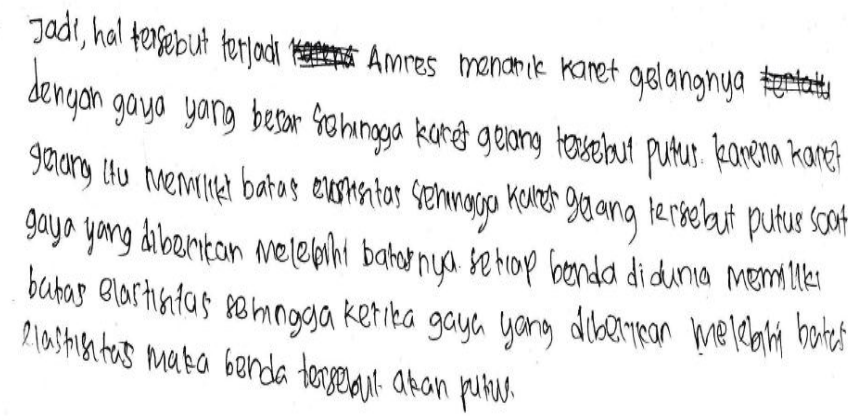

Gbr. 7. Jawaban pemahaman konsep nomor 5 kategori tinggi kelas eksperimen 


\section{5. hal tersebut tegings kavena gaya youg skaluarkan Amves terlalu besar. Setiap benda memilik batas elastisitas, jad saat Amres menari'k karet tersebut dengan gaya young besar maka karef terscout otomatis a kan putus. Karena karet itu sudah melebihi batas elastisitasung}

Gbr. 8. Jawaban pemahaman konsep nomor 5 kategori tinggi kelas kontrol

Kategori ini kedua siswa baik dari kelas kontrol dan eksperimen mampu menjawab soal nomor 5 dengan benar sehingga tidak ada perbedaan jawaban dari kedua siswa tersebut secara signifikan. Pada kelas eksperimen siswa mampu menjawab dengan benar karena pada pendekatan CPS yang digunakan dalam penelitian ini memiliki beberapa tahap. Tahap pertama yaitu tahap pendahuluan dimana pada tahap ini guru mengemukakan isu/masalah yang ada kepada siswa yang akan dipecahkan siswa untuk menggali pemahaman awal siswa terkait pada materi elastisitas. Dikarenakan isuisu tersebut mereka dapat bertukar pikiran dengan teman maupun guru sehingga wawasan dan daya pikir mereka lebih berkembang. Pada tahap ini Misalnya pada pertemuan pertama, peneliti memberikan pertanyaan kepada siswa "jika kalian cermati, mengapa pegas yang ditarik dengan gaya yang lebih besar panjangnya juga bertambah"? Kemudian siswa menjawab sesuai dengan apa yang mereka lihat dan ketahui. Tahap kedua yaitu mendeskripsikan masalah dalam bentuk fisika atau pembentukan konsep, dimana pada tahap ini guru menjelaskan tentang materi yang akan diajarkan. Pada tahap ini peneliti menanamkan konsep yang berkaitan dengan materi yang diajarkan.

Selanjutnya Setelah siswa paham dengan materi tersebut, maka beranjak ketahap ketiga yaitu tahap merencanakan solusi. Pada tahap ini siswa dituntut untuk mampu menerapkan konsep dari materi tersebut dalam melakukan percobaan. Tahap terakhir adalah evaluasi atau pemantapan konsep, dimana guru dan siswa melakukan tanya jawab tentang hal-hal yang belum dipahami oleh siswa. Setelah tidak ada miskonsepsi maka guru memberikan soal yang berkaitan dengan materi yang disampaikan [11].

Hal yang berbeda terjadi pada soal nomor 9, dimana kelas eksperimen menjawab dengan jawaban benar dan kelas kontrol menjawab dengan jawaban yang salah, adapun jawaban siswa sebagai berikut:

$$
\begin{aligned}
& \text { 9. hal tersebut tersad kanena nilal modulus elastintas } \\
& \text { totapt bahan peryusumnua berbeda. dan kerika bahen peryu humya } \\
& \text { berbeda, maka hirai modelus elartisitasnya pun a kan beribeda sehings }
\end{aligned}
$$

Gbr. 9. Jawaban pemahaman konsep nomor 9 kategori tinggi kelas eksperimen

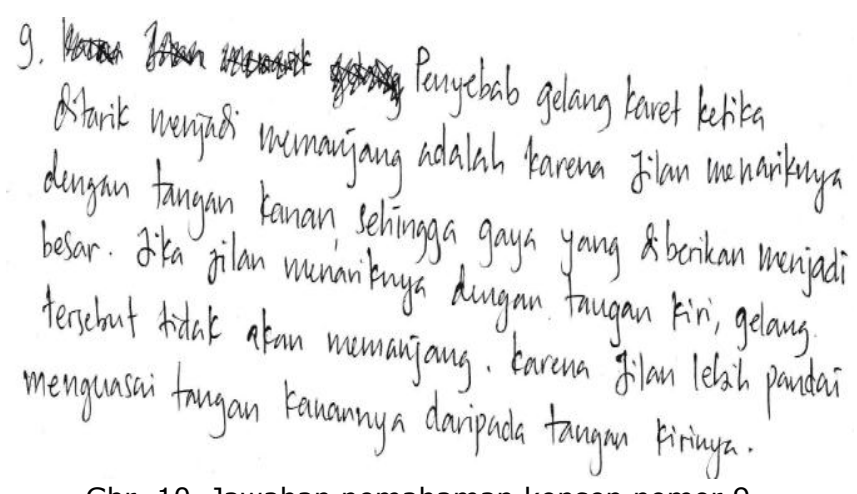

Gbr. 10. Jawaban pemahaman konsep nomor 9 kategori tinggi kelas kontrol

Perbedaan yang mencolok dari jawaban tersebut adalah jawaban kelas eksperimen logis dan sesuai konsep yang diajarkan oleh peneliti setelah penerapan pendekatan CPS sehingga siswa dapat memahami permasalahan soal yang diberikan dengan baik. Sementara pada kelas kontrol jawabannya salah karena terlalu banyak kemungkinan yang dipikirkan sebagai contoh tangan yang digunakan untuk menarik, padahal didalam soal tersebut tidak dikatakan bahwa anak yang menarik gelang karet tersebut menarik dengan tangan yang beda, sehingga menurut peneliti pada kategori tinggi soal nomor 9 anak tersebut belum memahami soal secara sepenuhnya.

Adapun skor rata-rata yang diperoleh siswa pada kelas kontrol setelah perlakuan lebih rendah dibandingkan kelas experiman. Hal ini karena model pembelajaran yang diterapkan pada kelas kontrol dan praktikum hanya berupa demonstrasi percobaan, sehingga terdapat beberapa siswa kurang aktif dan kurang perhatian dalam mengikuti pembelajaran.

Untuk kategori sedang pada kelas eksperimen dan kelas kontrol juga memiliki variasi jawaban yang sama dengan kategori tinggi, misalkan soal nomor 8 baik kelas eksperimen dan kelas kontrol menjawab dengan jawaban yang benar seperti yang terlihat pada gambar dibawah ini: 


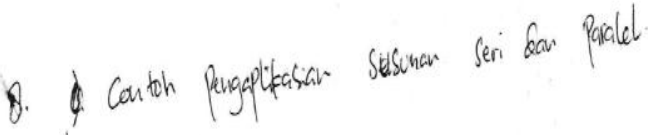
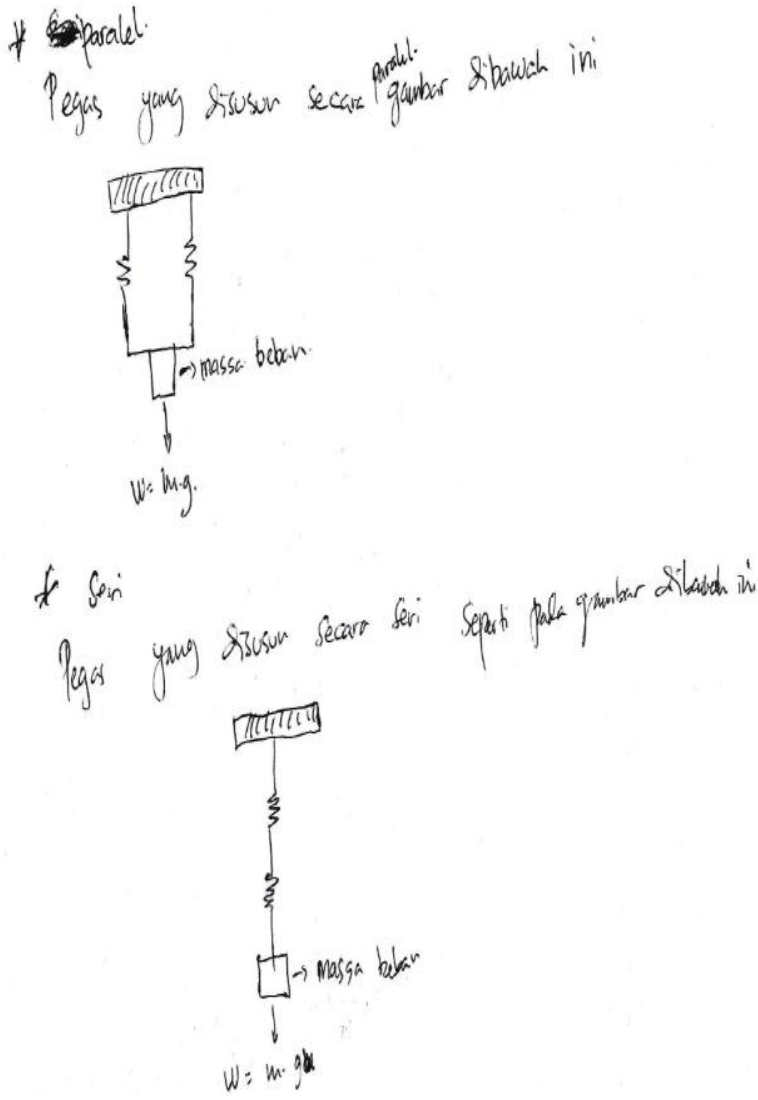

Gbr. 11. Jawaban pemahaman konsep nomor 8 kategori sedang kelas kontrol

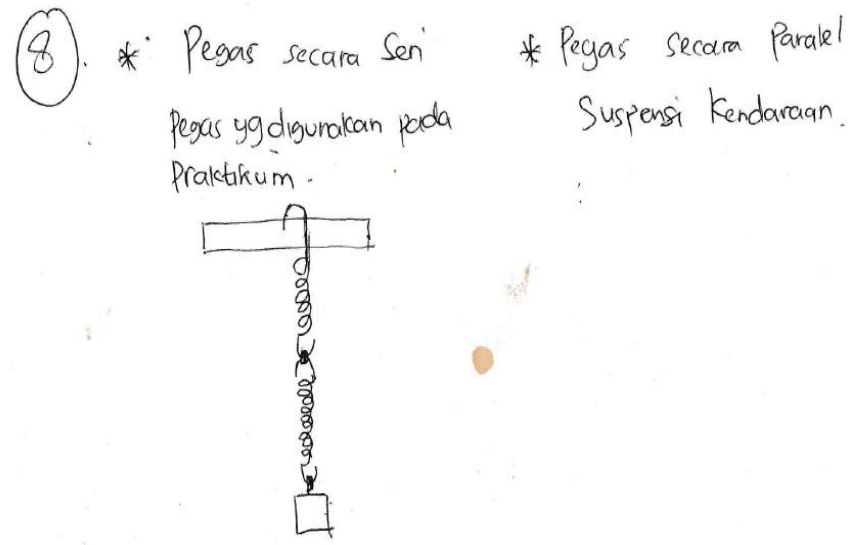

Gbr. 12. Jawaban pemahaman konsep nomor 8 kategori sedang kelas eksperimen

Variasi jawaban yang lainnya dimana kelas eksperimen menjawab dengan benar dan kelas kontrol menjawab dengan salah terlihat pada soal nomor 6 dengan jawaban sebagai berikut:

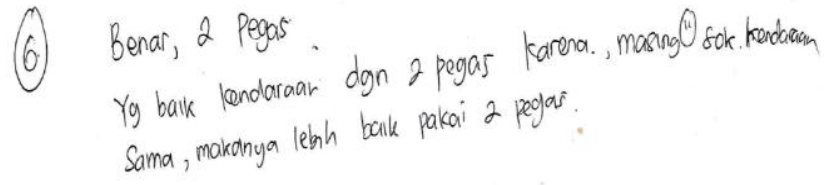

Gbr. 13. Jawaban pemahaman konsep nomor 6 kategori sedang kelas eksperimen

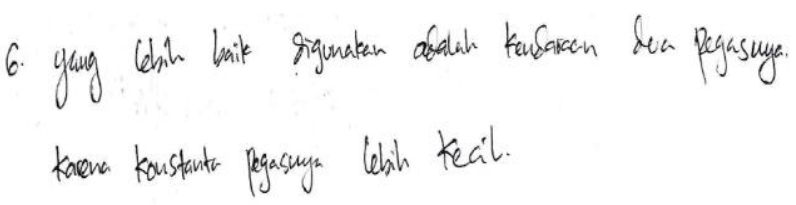

Gbr. 14. Jawaban pemahaman konsep nomor 6 kategori sedang kelas kontrol

Dari paparan jawaban diatas dapat ditarik kesimpulan bahwa kelas eksperimen dengan pendekatan CPS lebih baik jawabannya dibandingkan kelas kontrol. Kalau cermati soal nomor 6 memiliki 2 pertanyaan. Pertanyaan pertama adalah mana yang lebih baik dan pertanyaan kedua adalah alasan mengapa memilih jawaban tersebut. Anak pada kelas eksperimen mampu menjawab dengan benar dan alasan yang tepat. Sementara anak yang diajar dengan pembelajaran konvensional jawaban benar tetapi alasan tidak tepat. Hal tersebut dikarenakan pendekatan CPS memudahkan siswa untuk dapat memahami materi karena siswa diajak untuk memahami fenomena yang berkaitan dengan materi pada kehidupan sehari-hari. Selain itu siswa juga diajak untuk mengaplikasikan dalam praktikum sehingga siswa mendapatkan kesempatan untuk bereksperimen dan menyelesaikan masalah dengan menerapkan konsep yang telah dipelajari sebelumnya. Dengan melakukan eksperimen maka siswa dapat mengalami sendiri dan membekas dalam ingatan mereka. Dengan demikian pendekatan CPS dapat meningkatkan pemahaman konsep siswa.

Untuk kategori rendah pada kelas eksperimen dan kelas kontrol juga memiliki variasi jawaban yang sama dengan kategori tinggi dan sedang, misalkan soal nomor 6, kelas eksperimen menjawab dengan benar dan kelas kontrol menjawab dengan jawaban yang benar tetapi alasan kurang tepat seperti yang terlihat pada gambar dibawah ini:

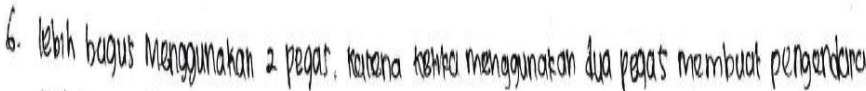

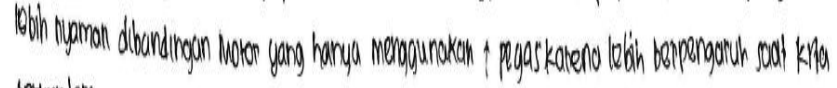
betrentoro.

Gbr. 15. Jawaban pemahaman konsep nomor 6 kategori rendah kelas eksperimen

6. Yang lebih bagus adalah menggunakan 2 pegas. Karena jika menggunakan a pegas, maka motor yang dimiliki

Gbr. 16. Jawaban pemahaman konsep nomor 6 kategori rendah kelas kontrol 
Perbedaan yang terlihat dalam kategori ini adalah kelas eksperimen yang diterapkan pendekatan CPS menjawab dengan benar sementara anak yang di ajar dengan pendekatan konvensional jawabannya benar tetapi alasannya tidak tepat. Contoh untuk siswa dengan kategori rendah dengan variasi jawaban soal yang sama adalah soal nomor 3, dimana siswa tersebut tidak menjawab pertanyaan yang diberikan kepada mereka. Pada kelas kontrol siswa kebanyakan tidak terbiasa dengan soal yang diberikan sehingga siswa kebanyakan akan menjawab dengan salah atau lari dari konsep fisika yang diajarkan karena pendekatan konvensional yang dilakukan hanya berpusat pada kemampuan matematis siswa saja [12].

\section{KESIMPULAN}

Berdasarkan hasil penelitian dan analisis data maka dapat disimpulkan bahwa penerapan pendekatan CPS berpengaruh terhadap pemahaman konsep dan problem solving siswa kelas XI SMA Negeri 3 Palu. Hal ini bisa dilihat pada uji statistik yang digunakan dimana untuk soal tes awal nilai Sig. > 0,05 yang artinya Ho ditolak dan tidak terdapat perbedaan siswa dalam problem solving dan pemahaman konsep, tetapi untuk uji $t$ pada tes akhir didapatkan nilai Sig. < 0,05 yang berarti Ho ditolak dan $\mathrm{H} 1$ diterima dimana terdapat perbedaan yang signifikan antara pemahan konsep dan kemampuan problem solving siswa.

\section{DAFTAR PUSTAKA}

[1] Sabia Zulkifli. 2012. Analisis penggunaan waktu oleh guru dan siswa dalam tahap-tahap physcis problem solving. Tesis, tidak diterbitkan. Palu: Program Pascasarjana UNTAD.

[2] Larkin J dan Reif F. 1981. Understanding and teaching problem solving in physics. Int. J. Sci. Educ. 1, 191

[3] Jennifer $L$ dan Jose. 2012. Impact of a short intervention on novices' categorization criteria. Phys. Rev. ST Phys. Educ. Res. 8, 020102

[4] Heuvelen A. 1991. Learning to think like a physicist: A review of research-based instructional strategies. Am. J. Phys. 59, 891.

[5] Mestre J, Dufresne R, Gerace W, Hardiman dan J Touger. 1993. Promoting skilled problem-solving behavior among beginning physics students. J. Res. Sci. Teach. 30, 303

[6] Gautreau R dan Novemsky L. 1997. Concepts firstA small group approach to physics learning. Am. J. Phys. 65, 418

[7] Jennifer L dan Jose. 2015. Conceptual problem solving in high school physics. Phys. Rev. ST Phys. Educ. Res. 11, 020106

[8] Sudjana.1996. Metode Statistika. Bandung: Tarstid

[9] Supriyadi, Nurjannah dan Haeruddin. 2016. Peningkatan kemampuan memecahkan masalah fisika antara model penalaran kausal berbasis etnosains dengan sains modern. JRKPF UAD Vol.3 No.2

[10] Hariawan, Kamaluddin dan W Unggul. 2014. Pengaruh model pembelajaran creative problem solving terhadap kemampuan memecahkan masalah fisika kelas XI SMA Negeri 4 Palu. JPFT. Vol. 1 No. 1 ISSN 23383240

[11] Faradina Arini, W Unggul dan Saehana S. 2016. Perbedaan pemahaman konsep kalor antara siswa yang belajar melalui model pembelajaran sains teknologi masyarakat dengan pembelajaran konvensional di SMA Negeri 4 Palu. JPFT. Vol. 4 No. 4 ISSN 23383240

[12] Walsh L, Howard dan B Bowe. 2007. Phenomenographic study of students' problem solving approaches in physics, Phys. Rev. ST Phys. Educ. Res. 3, 020108 